[DOI: 10.24214/jecet.A.8.1.01422.]

Juurnal of Enviranmental Science, Computer Science and Engineering \& Technology

An International Peer Review E-3 Journal of Sciences and Technology

Available online at www.jecet.org

Section A: Environmental Science

Research Article

\title{
Spent Catalyst Coming Out from Ammonia Synthesis Fertilizer Plant and Impact on Environment
}

\author{
R. P. Prajapati \\ Department of Chemistry (DESM) Regional Institute of Education (NCERT) Bhopal 462013 India
}

Received: 20 November 2018; Revised: 06 December 2018; Accepted: 10 December 2018

\begin{abstract}
Ammonia is primarily used as nitrogenous fertilizer and as a raw material of inorganic compounds including nitric acid, ammonia salts, cyanide and organic compounds, such as amines, sulfanilamide and so on. In addition, ammonia is also an excellent refrigerant. Since ammonia is a key raw material for industry and agriculture, the process of ammonia synthesis has an extremely important position in any economy. During ammonia synthesis in nitrogenous fertilizer plant for production of nitrogenous fertilizer and other products, the major reactions of production and purification of synthesis gas and the synthesis of ammonia, all the carried out over different catalysts (Prajapati, R. P., Sharma Anand and Tiwari, D. R., 2010). At least eight kinds of catalyst used in the whole process, where natural gas or naphtha is used a feedstock and steam reforming is used to produce synthesis gas. These catalyst, are Co-Mo hydrogenation catalyst, zinc oxide desulfurizer, primary and secondary, steam reforming catalysts, high and low temperature shift catalysts, methanation catalyst and ammonia synthesis catalyst etc. In every catalytic operation, activity of the catalyst gradually decreases. Due to structural changes, poisoning, or deposition of extraneous material. A catalyst, which can no longer perform its original duty is referred to as "spent catalyst". In such cases fresh catalysts have to be substituted and the spent catalyst will be discarded as solid waste material. Disposal of spent catalyst is a problem as it falls under the category of hazardous industrial waste. Environmental laws concerning spent catalyst disposal have becomes increasingly more serve in recent years. Metals such $\mathrm{Ni}, \mathrm{Mo}, \mathrm{Fe}, \mathrm{Co}, \mathrm{Cu}, \mathrm{Zn}$ and $\mathrm{Cr}$ present in the spent catalyst can leached by water after disposal and pollute the
\end{abstract}


environment. These metals exert wide variety of adverse effects on human being. Some of the metals have extremely long biological half-life that essentially makes it a cumulative toxin. Also some metals are carcinogenic in nature. Hence these solid waste materials which are causing serous environmental problems can act as artificial ores. The valuable metals can be recovered from these spent catalyst waste ${ }^{1}$. Recovery of metals from spent catalysts solid wastes has been an important issue not only from economic aspect but also for recycling rare natural sources and reducing the spent catalyst waste to prevent the environmental pollution.

Keywords: Catalyst, Deactivation, Spent catalyst, Ammonia synthesis, Solid hazardous waste, Environmental pollution, adverse effect, Metal reclamation.

\section{INTRODUCTION}

The word "catalyst" comes from the Greek word "katalein" which means decompose. This concept was introduced and explained in 1835 by Jons Jacob Berzelius. The phenomenon of catalysis is associated with a change of chemical reaction rate in addition of a chemical compound called a catalyst. Catalysis is the key to chemical transformations. Most industrial synthesis and processes require catalysis. Large quantities of catalysts are used in the fertilizer industry (i. e. ammonia plant), in petroleum refineries, in the chemicals sector, in various conversion processes, and in automotive catalytic converters for pollution control. The development of chemical products in advanced. Industrialized societies are technically, economically and ecologically possible by means of specific catalysts. $95 \%$ of all products (volume) are synthesized by means of catalysis while $20 \%$ of the world economy depends directly or indirectly on catalysis ${ }^{2}$. The importance of catalysis to chemical processes is enormous. An estimated $70 \%$ of all the chemical products (processes) are based on catalytic technologies. It has been estimated that more than $80 \%$ of the added value in chemical industry is based on catalysis. Approximately $80 \%$ of all catalytic processes require heterogeneous catalysts.

Ammonia is very important chemical which used as raw material for manufacturing of different chemicals such as nitrogenous fertilizer, nitric acid, cyanide, amine and organic compounds. In the $19^{\text {th }}$ century, ammonia was obtained from natural saltpeter or recovered from coal. In order to meet the increasing demand for nitrogenous fertilizers, a variety of methods were tried to fix nitrogen from air at the beginning of the $20^{\text {th }}$ century. Catalytic ammonia synthesis from $\mathrm{N}_{2}$ and $\mathrm{H}_{2}$ was developed by Fritz Haber, and then Carl Bosch applied this process to industrial production successfully at the beginning of $20^{\text {th }}$ century. Because of the extensive use of nitrogenous fertilizers, catalytic ammonia synthesis plays an important role in agriculture and other industries. This industrial importance has been paralleled by a significant scientific interest in understanding and improving the ammonia synthesis catalyst ${ }^{3}$. Often new techniques, methods and theories of catalysis have initially been developed and applied in connection with studies of this system. Similarly, new discoveries in the field of ammonia synthesis have been extended to other areas of catalysis. The combined influence of refined characterization techniques, improved kinetic analysis, and new possibilities in theoretical modeling, has led to a detailed insight into the fundamentals of ammonia synthesis catalyst.

Synthesis of ammonia in different plant depends on raw materials and catalysts used in synthesis process. Ammonia is basically produced from water, air and energy. The source of energy is normally coal or hydrocarbons which are reacted with water at high temperature and electricity to drive the compressors. Natural gas is generally the preferred hydrocarbon: some $77 \%$ of world ammonia production capacity is currently based on natural gas and more than $99 \%$ of world nitrogenous 
fertilizer production is based on ammonia. In ammonia production plant different type of catalysts are used Singh $^{4}$.

They are generally supported on porous materials like alumina and silica through precipitation or impregnation processes. Mostly metals are in the form of oxides, however, in the other cases, they are reduced into active metals for catalyzing the appropriate reactions. After periodical use of the catalysts, due to poisoning effect of foreign material and impurities, which deposit on the surface of the catalyst, they will become inactive or spent or poisoned due to loss of surface area. The causes of deactivation are basically threefold: chemical, mechanical and thermal. In such cases, fresh catalysts have to be after 5-7 years and the spent catalyst will be discarded as waste material ${ }^{5}$. Environmental laws concerning spent catalyst disposal have become increasingly more severe in recent years. Disposal of spent catalyst is a problem as it falls under the category of hazardous industrial waste. Spent catalysts have been classified as hazardous wastes by the United States Environment Protection Agency (USEPA) therefore spent catalyst should be again utilize an environmentally acceptable safe materials for recycle ${ }^{6}$. Several alternative methods such as disposal in land fills, reclamation of metals, regeneration/ rejuvenation and reuse, and utilization as raw materials to produce other useful products are available to the refiners to deal with the spent catalyst problem. The choice between these options depends on technical feasibility and economic considerations. Among all these methods metal reclamation has attained maximum attention as the recovered metals from spent catalysts.

\section{AMMONIA SYNTHESIS AND SPENT CATALYST}

Different types of catalysts are used in ammonia synthesis plant fertilizer industry. The improvement of catalysts not only increases the efficiency of production of ammonia, but also saves consumption of the power. Although a lot of technology progress has been achieved, the basic principles and process in modern ammonia plants are essentially the same as original ones developed by Haber and Bosch, a century ago. Ammonia is produced from atmospheric nitrogen and hydrogen from a hydrocarbon source. Natural gas is the most commonly used hydrocarbon feedstock for new plant; other feedstock's that have been used include naphtha, oil and gasified coal. More than $77 \%$ of world ammonia production capacity is currently based on natural gas. During ammonia synthesis, the major reaction of production and purification of synthesis gas and the ammonia, all are carried out over different catalysts ${ }^{7-10}$. At least eight kinds of catalysts are used in the whole process, where natural gas or naphtha is used as feedstock and steam reforming is used to produce synthesis gas. These catalysts are Co-Mo hydrocarbon catalyst, zinc oxide desulfurizer, primary and secondary steam reforming catalysts, high and low temperature shift catalysts, methanation catalyst and ammonia synthesis catalyst etc ${ }^{2}$. Details of the various catalysts used in the ammonia synthesis plant are given in table-1.

The eight kinds of catalysts may be roughly classified as "protective catalysts and economic catalysts". Co-Mo hydrogenation catalyst and zinc oxide desulfurizer are the protective catalyst for the primary steam reforming catalysts. The high-temperature shift catalyst protects the lowtemperature shift catalyst, and the methanation catalyst is the protective catalyst for ammonia synthesis catalyst. The catalysts for primary and secondary steam reforming, low-temperature shift and ammonia synthesis are responsible for the conversions of raw materials and the yield of products, and have direct effect on economic benefits of the whole plant, and are thus called as "economic catalysts" 11 . The amount of catalysts used depends on the process and raw material. The process flow diagram for ammonia synthesis given as Fig. 1. 
Table 1: Catalysts used in the ammonia synthesis plant (fertilizer industry)

\begin{tabular}{|c|c|c|c|c|c|}
\hline $\begin{array}{l}\mathbf{S} . \\
\mathbf{N}\end{array}$ & Process & Catalyst & Catalytic Reaction & $\begin{array}{c}\text { Life } \\
\text { (years) }\end{array}$ & $\begin{array}{c}\text { Nature of } \\
\text { spent } \\
\text { catalyst }\end{array}$ \\
\hline 1 & $\begin{array}{l}\text { Hydrosulf } \\
\text { urisation }\end{array}$ & $\mathrm{Co} / \mathrm{Mo} / \mathrm{Al}_{2} \mathrm{O}_{3}$ & $\mathrm{R}_{2} \mathrm{~S}+2 \mathrm{H}_{2} \rightarrow 2 \mathrm{RH}+\mathrm{H}_{2} \mathrm{~S}$ & $5-7$ & Pyrophoric \\
\hline 2 & $\begin{array}{l}\text { Desulphu } \\
\text { risation }\end{array}$ & $\mathrm{ZnO}$ & $\mathrm{H}_{2} \mathrm{~S}+\mathrm{ZnO} \rightarrow \mathrm{ZnS}+\mathrm{H}_{2} \mathrm{O}$ & $\begin{array}{l}\text { depends } \\
\text { on the S- } \\
\text { content in } \\
\text { Natural } \\
\text { gas }\end{array}$ & $\begin{array}{l}\text { Non- } \\
\text { Pyrophoric }\end{array}$ \\
\hline 3 & $\begin{array}{l}\text { Primary } \\
\text { reforming }\end{array}$ & $\mathrm{NiO}$ & $\mathrm{CH}_{4}+\mathrm{H}_{2} \mathrm{O} \rightarrow \mathrm{CO}+3 \mathrm{H}_{2}$ & $5-7$ & Pyrophoric \\
\hline 4 & $\begin{array}{l}\text { Secondar } \\
\text { y } \\
\text { reforming }\end{array}$ & $\mathrm{NiO}$ & $\mathrm{CH}_{4}+1 / 2 \mathrm{O}_{2} \rightarrow \mathrm{CO}+2 \mathrm{H}_{2}$ & $5-7$ & Pyrophoric \\
\hline 5 & $\begin{array}{l}\text { High } \\
\text { temperatu } \\
\text { re shift } \\
\text { converter }\end{array}$ & $\mathrm{Fe}_{2} \mathrm{O}_{3} \& \mathrm{Cr}_{2} \mathrm{O}_{3}$ & $\mathrm{CO}+\mathrm{H}_{2} \mathrm{O} \rightarrow \mathrm{CO}_{2}+\mathrm{H}_{2}$ & $5-7$ & Pyrophoric \\
\hline 6 & $\begin{array}{l}\text { Low } \\
\text { temperatu } \\
\text { re shift } \\
\text { converter }\end{array}$ & $\mathrm{CuO}, \mathrm{ZnO} \& \mathrm{Al}_{2} \mathrm{O}$ & $\mathrm{CO}+\mathrm{H}_{2} \mathrm{O} \rightarrow \mathrm{CO}_{2}+\mathrm{H}_{2}$ & $5-7$ & Pyrophoric \\
\hline 7 & $\begin{array}{l}\text { Methanati } \\
\text { on } \\
\text { converter }\end{array}$ & $\mathrm{Ni}$ & $\mathrm{CO} / \mathrm{CO}_{2}+6 \mathrm{H}_{2} \rightarrow \mathrm{CH}_{4}+\mathrm{H}_{2} \mathrm{O}$ & $5-7$ & Pyrophoric \\
\hline 8 & $\begin{array}{l}\text { Ammonia } \\
\text { Converter }\end{array}$ & $\mathrm{Fe}_{3} \mathrm{O}_{4}$ & $\mathrm{~N}_{2}+3 \mathrm{H}_{2} \rightarrow 2 \mathrm{NH}_{3}$ & $5-7$ & Pyrophoric \\
\hline
\end{tabular}


Fig. 1: Process flow diagram for ammonia synthesis

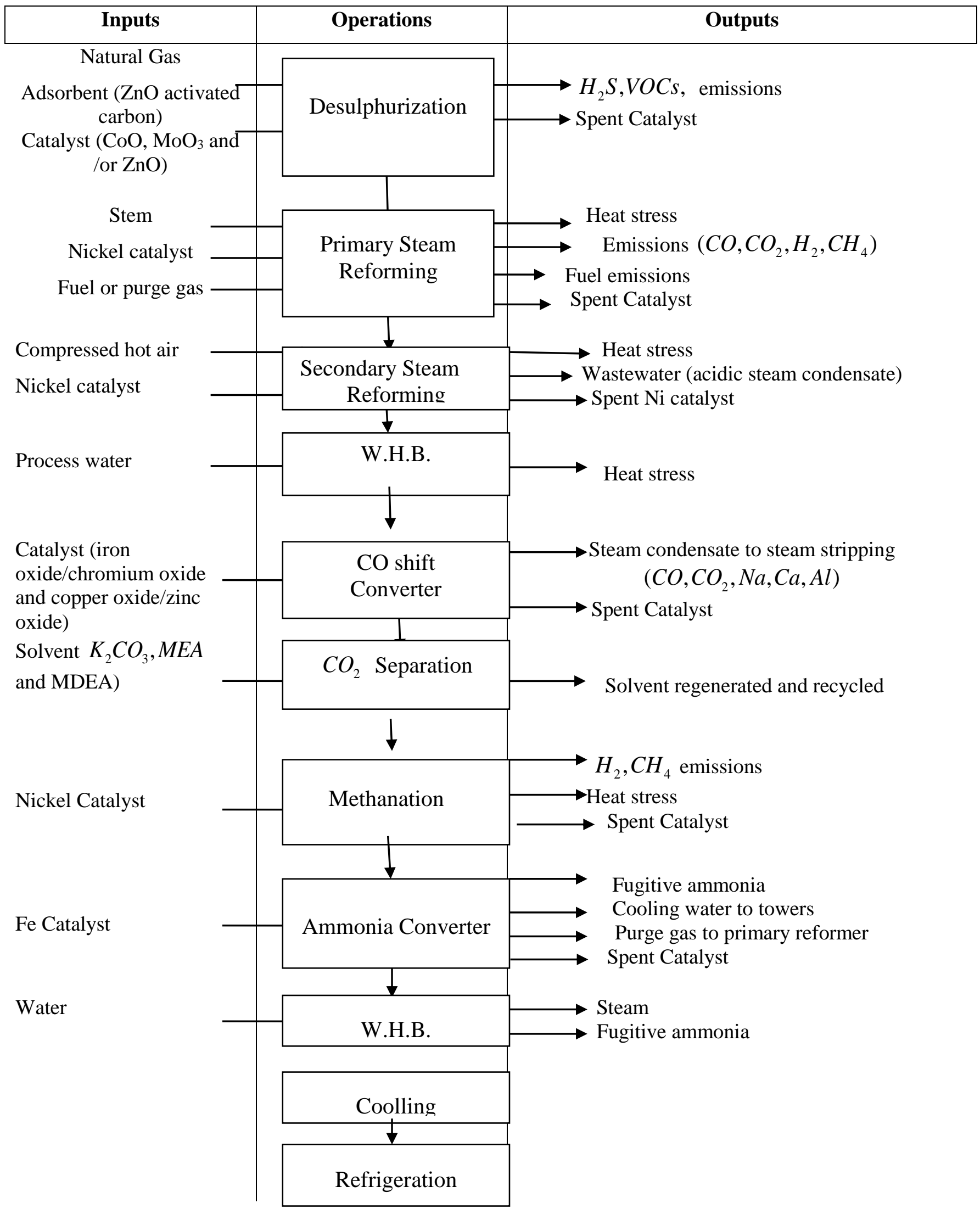


Metals like $\mathrm{Ni}, \mathrm{Mo}, \mathrm{Co}, \mathrm{Cu}, \mathrm{Zn}$ and $\mathrm{Fe}$ are coldly used as a catalyst in ammonia synthesis plant. They are generally supported on porous materials like alumina and silica. After periodical use of the catalysts (5-7), due to poisoning effect of foreign material and impurities, which deposit on the surface of the catalyst, they will become inactive. In such cases, fresh catalysts have to be substituted and the spent catalyst will be discarded as waste materials. Disposal of spent catalyst is a problem as it falls under the category of hazardous industrial waste. Therefore the spent catalyst is attracting the attention of environmental authorities in many countries and the refiners are experiencing pressures from environmental authorities for safe handling, management and utilization of spent catalysts 12 .

\section{ADVERSE EFFECT OF SPENT CATALYST ON ENVIRONMENT}

Ammonia is primarily used as nitrogenous fertilizer and as a raw material of inorganic and organic compound. In addition, ammonia is also an excellent refrigerant. During the ammonia synthesis, in industrial plant generates so many spent catalysts. These spent catalysts (solid wastes) possess toxic elements such as heavy metals. Improper disposal of these wastes becomes a key factor in metal contamination and thus when leached into environment cause serious environmental problem. Metal such as $\mathrm{Ni}, \mathrm{Mo}, \mathrm{Co}, \mathrm{Zn}$ and $\mathrm{Cu}$ present in the catalyst can leached by water after disposal and pollute the environment. Besides the formation of leachates, the spent catalysts, when in contact with water, can liberate toxic gases.

The formation of dangerous $\mathrm{HCN}$ gas from coke deposited on spent catalysts that contains substantial amount of nitrogen has been reported. Metal containing spent catalysts exert wide variety of adverse effects on human being and flora and fauna ${ }^{13}$. Some of the metals have extremely long biological half-life that essentially makes it a cumulative toxin. Also some metals are carcinogenic in nature. Therefore environmental laws concerning spent catalyst disposal have becomes increasingly more severe in recent years. Due to this spent catalysts have been classified as hazardous wastes by the Environmental Protection Agency (EPA) in the USA, and need to proper utilization and management of spent catalyst for minimization of environmental pollution.

\section{NEW TRENDS IN UTILIZATION AS RECOVERY OF METAL FROM SPENT CATALYST AND MANAGEMENT}

The quantity of spent catalyst discarded as solid waste can be reduced, if the useful life of the catalyst before disposal could be extended for a longer period. Several alternative methods such as reclamation of metals, regeneration/rejuvenation, reuse and utilization as raw materials to produce other useful products are available to deal with the spent catalyst problem. The choice between these options depends on technical feasibility and economic consideration. Nowadays, in order to alleviate the shortage of domestic resources and improve the environmental condition, many countries in the world pay much attention to the comprehensive utilization of the secondary resources ${ }^{14}$.

This has presented an opportunity for new business to rejuvenate, recycle and convert the spent catalyst to an environmentally acceptable safe material for recycle. Among all these methods metals reclamation has attained maximum attention as the recovered metals such as $\mathrm{Mo}, \mathrm{Co}, \mathrm{Ni}, \mathrm{Cu}, \mathrm{Al}$, and $\mathrm{Zn}$ could be used in different purpose and the alumina could be used for the manufacture of refractory, ceramics and abrasives ${ }^{15}$. The metal reclamation option can provide a complete solution to the environmental problem of spent catalysts in a profitable way. This option, however, doesn't provide a complete solution of all types of catalysts. 
Spent catalysts (solid wastes) can act as potential source for heavy metals and in this sense these solid wastes can act as artificial ores. The valuable metals can be recovered from these spent catalysts. There are varieties of methods in use for recovery of heavy metals. These include pyrometallurgical, hydrometallurgical and biometallurgicall methods. Pyrometallurgical recovery consists of the thermal treatment of ores and metal containing spent catalysts to bring about physical and chemical transformation.

This enables recovery of valuable metals: calcinig, roasting, smelting and refining are the pyrometallurgical processes used for metal recovery ${ }^{16}$. The hydrometallurgy recovery uses mainly the leaching process. It involves the use of aqueous solutions containing a lixiviate which is brought into contact with a material containing a valuable metal. Further the metals are concentrated and purified by using precipitation, cementation methods. Bio-hydrometallurgical process is one of the most promising and revolutionary biotechnologies. This technique exploits microbiological process for recovery of heavy metal ions.

In last few decades the concept of microbiological leaching has played a greater role to recover valuable metals from various sulphide minerals or low grade ores ${ }^{17}$. Now the microbiological leaching process has been shifted for its application to recover valuable metal from the different spent catalyst waste of plant. Among the bacteria Acidithiobacillus Ferrooxidans, Acidithiobacillus thiooxidans, Leptospirillum Ferrooxidans, and sulfolobus sp, are well known for the bioleaching activity while penicillium, and Aspergillus niger are some fungi those help in metal leaching process. The process of recovery makes sense only if the cost of recovery is much less than the value of the metal $^{18}$.

Considering this bio-hydrometallurgical recovery of heavy metals from industrial spent catalyst waste appears to be an attractive treatment technique. Almost without exception, microbial extraction procedures are more environment friendly, while giving high extraction yield in excess of $90 \%$. In future, new strains have to be identified to improve the metal recovery from spent catalyst. The biohydrometallurgical processes are still at the laboratory scale. There is a need to advance commercial application of bio-hydrometallurgical processes ${ }^{19}$.

\section{CONCLUSIONS}

During ammonia synthesis in different plant so many catalysts are used. After periodically use of the catalyst due to the poisoning effect of foreign material and impurities, which deposit on the surface of the catalyst, they will become inactive. A catalyst, which can no longer perform its original duty, is referred to as "spent catalyst" and these are discarded as solid wastes by plant. The most important hazardous characteristic of spent catalysts is their toxic nature. In the ammonia synthesis industry, the amount of spent catalysts discarded as solid wastes has increased significantly in recent years because of demands of ammonia compound and rapid growth of nitrogenous fertilizer not only in India but also all over the world.

Because of their hazardous nature, increasing emphasis has been placed to minimize spent catalyst waste generation at source as well as to develop cost -effective methods for reprocessing and much as possible. Spent catalyst waste reduction at source can be achieved by using improved more active and more stable catalysts, regeneration/rejuvenation and reuse of deactivated catalysts in many cycles before the final disposal. The spent catalyst can be recycled by using them as raw materials for recovery of valuable metals and other products. 


\section{REFFRENCES}

1. M. Marafi and A. Stanislaus, Studies on rejuvenation of spent hydroprocessing catalysts by leaching of metal foulants, J. mole. Catal. A: che.,2003, 202:117-125.

2. J. Shen.(ed.) ,Synthesis ammonia in series of fertilizer engineering, Beijing: chemical industrial press,2001.

3. D.H. Xiang, Liu Hy, Practical handbook of fertilizer catalysts, Beijing: chemical industrial press, 1992, 45.

4. B. Singh, Treatment of spent catalyst from the nitrogenous fertilizer industry-A review of the available methods of regeneration, recovery and disposal, J. Hazard, material,2009, 167(1-3), 24-37.

5. Yu Zh, Zhu Bc, shen $\mathrm{Cd}$, et al. Analysis of process of large-scale plants for ammonia synthesis, Beijing;China petroleum press,1993,.

6. United Stated Environmental Protection Agency (USEPA), hazardous waste management system Fedral register,2003, 86 (202) 59935.

7. R. P Prajapati, Sharma Anand and D. R. Tiwari, Industrial hazardous waste management studies of nitrogenous chemical fertilizer factory in Vijaipur, District Guna (m. P.) India, current world environment,2010, 5 (1) 143-146.

8. R. P Prajapati, Sharma Anand and D. R. Tiwari, Electro-recovery of nickel from spent catalyst(solid waste) coming out from nitrogenous fertilizer industry OJC ,2010, 26(2), 721-723.

9. R. P Prajapati, Sharma Anand and D. R. Tiwari,Study on nitrogenous fertilizer industry spent catalyst as substitutes materials for production of hydrogen by steamiron process, OJS 2010, .26(3),1131-1134.

10. R. P Prajapati, Sharma Anand and D. R. Tiwari, Studies of some potential catalyst on the activity and deactivation process of low temperature co-conversion catalyst,OJS,2010, 26(1),331-334.

11. R.S. Tennison, J.R. Jennigs JR (ed.), Catalytic Ammonia synthesis. Chapter 9. Newyork:plenum press, 1991,.

12. R. P Prajapati, Sharma Anand and D. R. Tiwari, Utilization of spent catalyst (solid waste) from the nitrogenous chemical plant,OJS,2011, 27(3) 1289-1292.

13. R.P. Prajapati, R. Singhai, Impact assessment of fertilizer waste on environment, JECET, 2012, 1(3),311-315.

14. R. Rao, Resource recovery and recycling from metallurgical wastes, Oxfor. University, Elesevier,2006.

15. B.B. Kar, P. Datta, V.N. Misra, Spent catalyst:secondary source of Mo recovery, hydrometallurgy, 2004, 72, 87-92.

16. W. Mulak, A. Szymczycha-Madeja, B. Miazga, Recovery of metals from used hydrogenation catalysts used in the petrochemical industry, Ores and Non-Ferrous Metals, 2007, 8, 482-491 (in Polish). 
17. R.P. Prajapati, Spent catalyst (solid waste) of industry and Biohydrometallurgy, IJFAR, 2016, 3 (9), 10-13.

18. M. Hoque, O. Philip, (2011), Biotechnological recovery of heavy metals from secondary sources- An overview, Materials Science and Engineering ,2011, C 31, $57-66$.

19. Bosiovi and M. Vierra and E. Donati, Integrated bacterial process for the treatment of a spent Nickel catalyst, J. Hazard material,2008, 154 (1-3), 804-810.

* Corresponding Author: Dr. R.P. Prajapati

Assistant Professor in Chemistry Regional Institute of Education,

Bhopal 462013 